\title{
Analysis of Photovoltaic as Supporting Electric Power Supply on 02 Sultan Hasanuddin Training Vessel
}

\author{
Rukmini, Sukirno, Sahabuddin Sunusi, Paris J.Senda \\ Politeknik Ilmu Pelayaran Makassar \\ Jl. Tentara Pelajar No. 173 Makassar \\ e-mail:rukmini@pipmakassar.ac.id ; rukmini12mn@gmail.com
}

\begin{abstract}
This study aims to analyze the amount of electric power and the profit achieved under the installation of the Photovoltaic array. Solar panel tested was laid on the surface of the Training Ship 02 Sultan Hasanuddin. The technical analysis, namely the calculation of electrical power and economical use of Solar-Powered Electric to support the dieselpowered electric generator as the main source of electrical power. A comparison of power was made by measuring the electric current and voltage variable as well as the financial calculation between the diesel-powered and solar-powered electric generator. The financial calculation was analyzed by using NPV, IRR and PI methods. The results showed that since the power capacity of the Solar Panels was almost similar to the capacity of the Diesel Generator with the output power assumed to be similar, the Solar Panel that supports the Diesel Generator was more profitable than the use of Diesel Generators without supporting solar cells.
\end{abstract}

Keywords: Solar Cell, Diesel Generator, Technical Analysis, Financial Analysis

\section{Introduction}

Energy is increasingly becoming a basic need of every human being. There was an increase in the number of the energy used for industry, commerce, domestic usage, farming and transportation. Untill the present time, the needs of energy has relied on petroleum, coal and natural gas as the primary sources. In fact, the natural oil is getting rare and more expensive. The energy crisis seems to be a real threat in the future. Thus, continuous searching of the alternative energy to meet the electrical energy demand should be developed.

A solar cell is a device that can convert the ray of sunlight into electrical energy under the principle of photovoltaic. Solar cells used the direct energy converter technologies. Electrical energy can be created without the help of fluid movements such as steam or gas. Solar cells also do not require the movement of machineries such as a Rankine cycle or Brayton cycle.

Indonesia is a country that is located in equator line, where, throughout the year, it is exposed to the intense sunlight . Therefore, the utilization of solar energy by using photovoltaic is in a great demand and begin to be developed in all area of the country by doing a lot of research and testing. One of them is the study of hybrid system combining solar cell and the main electric power sources. A hybrid system is one alternative that can be applied to the transport and industry sectors with high power usage. The hybrid system utilizes renewable energy as the source of backup energy (secondary) combined with the

This paper is presented in The $4^{\text {th }}$ International Conference on Maritime Education and Training October $8^{\text {th }}$, 2020, Makassar, Indonesia 
main power source (primary). In the hybrid system, the renewable energy used can be derived from the energy of the sun, the wind, the waves and others that are combined with the main power source. This combination produces a power source that is efficient, effective and reliable to be able to supply the electrical energy needs in the transport sectors.

In relation to the development of alternative energy provision from the power generator besides the diesel fuel, the roof of the Training Ship 02 Sultan Hasanuddin PIP Makassar that has a flat surface area of $130 \mathrm{~m}^{2}$ can be used to receive the energy from the sunlight. Therefore, this research made the plan for installing photovoltaic by utilizing the roof of the Training Ship 02 Sultan Hasanuddin as the area for mounting the solar panel.

\section{Research Method}

The data was collected for 7 (seven) days on the study object of Training Ship 02 Sultan Hasanuddin managed by Politeknik Ilmu Pelayaran Makassar. The data collection methods used in this research were observation, documentation and literature studies.

\section{Material and Equipment used :}

1) Solar Panel, with: Max. Power (Pmax) is $300 \mathrm{~W}$; Nom. Power is ; $100 \mathrm{~W}$; Dimension 1956 x 992 x $40 \mathrm{~mm}$.

2) Inverter : Power $3000 \mathrm{~W}$

3) Battery Charge Regulator: 150A Solar Controller PV panel Battery Charge Controller Regulator 48V for $7200 \mathrm{~W}$

4) Battery ( Accu ) : 70 Ah (Ampere Hour), 12 V (Volt)

5) Fluke 325 Clamp Meter

6) Solar Panel Cable

7) LED

8) Solder set

9) Connector

\section{Data Analysis}

1. The technical procedure includes the calculation of power and the total electrical energy produced. The field observations on the solar panels systems that were capable of charging the electrical energy based on the time provided for 10 hours from 7 a.m. to 5 p.m.

2. Financial : The investment costs between the installation of Solar Panel and the provision of Diesel Generator set as well as the achievement of expected benefits

This type of research is an Experimental Research Development.

The references for the technical calculation include :

\section{The Calculation of Electric Power}

The calculation of electric power can be done with the following approach [6]:

$$
P=V \times I
$$

Where $: \mathrm{P} \quad=$ Electric power (watts)

$\mathrm{V}=$ Voltage (Volt)

I $=$ Electric current (Ampere)

So the electric power required can be identified. The electric power formula used to calculate the amount of power can be formulated as follows:

$$
P_{\text {battery }}=P_{\text {total }} \times T
$$


Where :

$$
\begin{gathered}
P_{\text {battery }}=\text { Power required }(\text { watt hour }) \\
P_{\text {total }}=\text { Total power }(\text { watt }) \\
\mathrm{T}=\text { Time of use (hour) }
\end{gathered}
$$

From this calculation, the selection of the battery was adjusted to the specifications that exist in the market by considering the maximum power produced by battery to meet the needs of the battery. So it will formulas as follows [6]:

Where :

$$
\begin{gathered}
n_{\text {needed }}=\frac{A H_{\text {needed }}}{A H_{\text {battery }}} \\
A H_{\text {needed }}=\frac{P_{\text {battery }}}{V_{S}}
\end{gathered}
$$

$$
\begin{aligned}
& \boldsymbol{A H}_{\text {needed }}=\text { the needed power of battery }(\mathrm{AH}) \\
& \boldsymbol{P}_{\text {battery }} \quad=\text { the needed power of system (watt hour) } \\
& \boldsymbol{V}_{\boldsymbol{S}} \quad=\text { the voltage of battery (Volt) }
\end{aligned}
$$

The calculation can be used to calculate the number of batteries that will be used to fulfil needs of solar power. The selection of the battery based on the specifications in accordance with the specifications that have been designed by the manufacturer of the battery and number of batteries required [6].

\section{The Calculation of Panel Area}

The panel area is the a surface where the Solar Cells will be placed. The wider the area available, the more solar cell that can be installed but the cost that will be incurred are also getting higher. The number of solar cell that can be mounted based on the following approach [7]:

$\mathrm{n}$ units of Solar Panel = the area available/A

\section{Cost Analysis}

The investation on solar cell system installation is a project or activity that involves capital expenditure, which is important economically because [9]:

1. The capital expenditures have long-term consequences. The capital expenditures will be latter forming activities of the company in the future and nature of the company in the long term.

2. The capital expenditure generally involves a very large number of money.

3. The commitment on capital expenditures is not easy to be changed.

In assessing the profit or loss of investment, there are several criteria to be used. The criteria for the assessment of investment can be classified into two groups. The first investment criteria based on the concept of advantage or profit is the average rate of return / accounting rate of return. The second investment criteria is based on the concept of cash flow that can be put in detailed as follows:

$$
\begin{array}{cl}
\text { where }: \boldsymbol{n}_{\text {needed }} & =\text { unit battery needed } \\
\boldsymbol{A} \boldsymbol{H}_{\text {needed }} & =\text { the needed power of battery }(\mathrm{AH}) \\
\boldsymbol{A H}_{\text {battery }} & =\text { the power output from battery }(\mathrm{AH})
\end{array}
$$


- The cash flow concept that disregards the time value of money or factor discount (nondiscount cash flow) is the payback period.

- The cash flow concept that takes into account the time value of money or discount cash flow, as follows [4]:

1) The Net Present Value (NPV)

2) Profitability index (PI)

3) Internal Rate of Return (IRR)

Therefore, it is required to perform the economic analysis on the investment of the installation of solar cell system in order to know the economical feasibility. The installation of the solar cell system can utilize the investment assessment criteria of the Net Present Value (NPV).

\section{- The PayBack Method}

This method tries to measure how fast an investment can recoup the fund used since the unit of result is not in the percentage, but in the unit of time (month, year, etc.). If the payback period is shorter than that implied by the management, then the investment project is said to be profitable, whereas if the payback period is longer, the project is said to be unprofitable.

Since this method measures time duration need to recover the funds invested, then the basis used is the cash flow, not profit. So it is formulated as follows [4]:

$$
\text { Payback }=\frac{\text { investment valus }}{\text { Cash flow }} \times 1 \text { year }
$$

\section{1) The Net Present Value (NPV) Method}

This method calculates the difference between the present value of the investment with the received net cash inflow (operational and cash flow) in the future. To calculate the present value, it is required to determined first level of interest that is considered relevant. There are several concepts to calculate the ones considered relevant to this. Basically, that interest rate is the interest rate when we consider the investment decision is still separate from the decision of spending or when we begin to continue the investment decisions with the spending decisions. The relatioship existed here only affects the interest rate, not the cash flow. If the present value of the receiving net cash inflow in the future greater than the present value of the investment, then the investment project can be said to be profitable.

Whereas, if it is smaller (NPV negative), the project is not profitable. [8].

The basic formula of the NPV is:

$$
\begin{aligned}
N P V=\text { investment value }- & \frac{\text { cash inflow }}{(1+i)} \\
+ & \frac{\text { cash inflow }}{(1+i)^{2}}+\ldots \ldots \frac{\text { cash in flow }}{(1+i)^{n}}
\end{aligned}
$$

Where $: \mathrm{n}=$ the number of years of depreciation of investments The NPV calculation created by projecting the calculation of income and expenses that occurred during the 25 years (based on the use of interest rates (interest) of $11 \%$ every year [5] 


\section{2) Internal Rate of Return (IRR) Method}

This method calculates the interest rate by equating the present value of the investment with the present value of the receipt net cash inflow in the future. If the interest rate is greater than the level of relevant (level of profit required), then the investment is said to be loss-making. With interest rate of $11 \%$ then : $16.11 \%$ For Photovoltaic (accepted). \#Num! For Diesel Generator (the value far away from the excel calculation and the result is rejected)

$$
N P V=\frac{\text { cash inflow }}{(1+r)}+\frac{\text { cash inflow }}{(1+r)^{2}}+\frac{\text { cash inflow }}{(1+r)^{3}}+\ldots \ldots \frac{\text { cash in flow }}{(1+r)^{n}}
$$

Where $: \mathrm{n}=$ the number of years of depreciation of investments [8].

\section{3) Profitability index (PI) Method}

This method calculates the interest rate by equating the present value of the investment with the present value of the receipt net cash inflow in the future. If the interest rate is greater than the level of relevant (level of profit required), then the investment is said to be loss-making or this method calculates the ratio between the value of net cash flows in the future with the present investment value. The Profitability Index should be greater than 1 to be considered worth. The greater the PI, the investment is more worth it [3]

\section{Results and Discussion}

\subsection{The Output Analysis of Power and Energy on daily recording}

Based on the results of the observation for 7 days by using 1 piece of solar panel, it revealed:

Table 1. Output Power (watt)

\begin{tabular}{|c|r|c|c|c|c|c|c|c|}
\hline \multirow{2}{*}{ No } & \multirow{2}{*}{ Time } & \multicolumn{7}{|c|}{ Total Power (Watt) } \\
\cline { 3 - 9 } & & Day 1 & Day 2 & Day 3 & Day 4 & Day 5 & Day 6 & Day 7 \\
\hline 1 & 7.00 & 150 & 149 & 147 & 151 & 154 & 158 & 158 \\
\hline 2 & 8.00 & 167 & 167 & 167 & 170 & 170 & 170 & 172 \\
\hline 3 & 9.00 & 173 & 173 & 173 & 186 & 185 & 189 & 189 \\
\hline 4 & 10.00 & 183 & 182 & 193 & 191 & 191 & 191 & 192 \\
\hline 5 & 11.00 & 190 & 190 & 200 & 200 & 194 & 194 & 197 \\
\hline 6 & 12.00 & 200 & 200 & 200 & 200 & 200 & 196 & 233 \\
\hline 7 & 13.00 & 200 & 197 & 195 & 192 & 192 & 192 & 191 \\
\hline 8 & 14.00 & 187 & 186 & 185 & 184 & 181 & 184 & 184 \\
\hline 9 & 15.00 & 183 & 182 & 172 & 173 & 173 & 170 & 170 \\
\hline 10 & 16.00 & 173 & 170 & 167 & 157 & 153 & 150 & 150 \\
\hline 11 & 17.00 & 153 & 157 & 147 & 145 & 145 & 135 & 142 \\
\hline
\end{tabular}




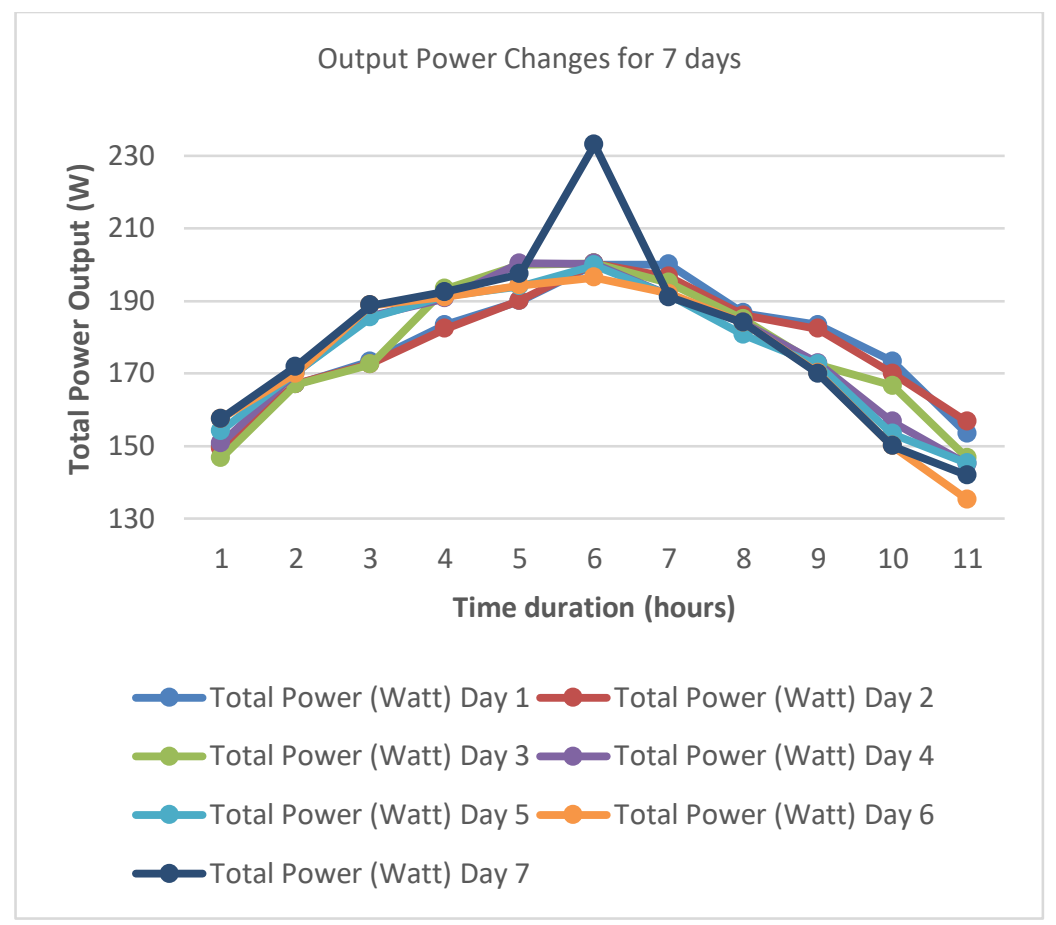

Figure 1. Output Power for 7 days

From figure 1. the visible increase in the output power of the solar panel was on day 7 (July 2020) at 12.00 p.m. which was equal to 233 watts. This was caused by the position of the sun that right above the surface of the earth.

Table 2. Total Energy Supply :

\begin{tabular}{|r|l|c|}
\hline No & Date & Output Energy (Watt. Hour) \\
\hline 1 & $09-05-2020$ & 1960 \\
\hline 2 & $16-05-2020$ & 1954 \\
\hline 3 & $13-06-2020$ & 1946 \\
\hline 4 & $20-06-2020$ & 1948 \\
\hline 5 & $27-06-2020$ & 1938 \\
\hline 6 & $11-07-2020$ & 1930 \\
\hline 7 & $18-07-2020$ & 1978 \\
\hline \multicolumn{3}{|c|}{ Average / Day } \\
\hline
\end{tabular}

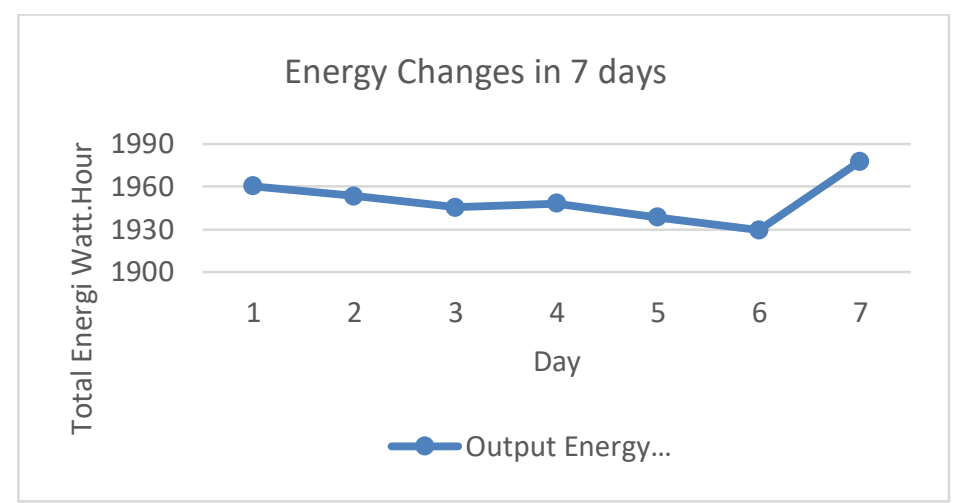

Figure 2. Total Supply Energy for 7 days 
From figure 2., the visible increase in the amount of electric energy for 10 hours in day 7 (July 2020) was equal to 1.951 watts.hour.

The results obtained by installing 1 piece of solar panel as the initial planning in training ship 02 Sultan Hasanuddin for 7 days were :

1.The maximum power that can be generated was 233 watts at day 7 and at 12.00 p.m local time.

2. The average energy on daily basis was 1,951 watts.hour.

Since on the MT. Sultan Hasanuddin Vessel has a surface area of $130 \mathrm{~m}^{2}$, while the crosssectional area of each solar panel is $100 \times 200 \mathrm{~cm}$, so by taking into account the distance of the gap for each panel, then in this study, it was assumed that the number of solar panels used was 10 units. Based on that assumption, the value of the maximum power and the average energy per day will be multiplied by 10 .

The Total Maximum Power per day for 10 pieces of solar panels was $\mathbf{2 , 3 3 0}$ watts and the energy average was 19,510 watts.hour.

The Calculation of the Cost of Investment for the 25 years usage duration

Cost of Investment for use in 25 years

Price list for the component and instalallation of Solar Panel

Table 3. Cost of Investment of PhotoVoltaic

\begin{tabular}{|c|c|c|c|c|c|c|}
\hline No & Material / Equipment & Qyt & Unit & \multicolumn{2}{|c|}{ Price } & Total \\
\hline 1 & Solar Panel 300WP & 10 & Pes & 3.900 .000 & Pes & 39.000 .000 \\
\hline 2 & Iron $50 \times 50 \times 4 \mathrm{~mm}$ & 100 & Meter & 129.950 & & 12.995 .000 \\
\hline 3 & Iron Hollow $40 \times 60 \times 2 \mathrm{~mm}$ & 50 & Meter & 180.000 & & 9.000 .000 \\
\hline 4 & Bolt M8x15mm & 100 & Pes & 500 & Pes & 50.000 \\
\hline 5 & Bolt M8x60mm & 60 & Pes & 1.000 & Pes & 60.000 \\
\hline 6 & Connector MC4 & 8 & Pes & 45.000 & Pes & 360.000 \\
\hline 7 & Connector MC4 Y & 4 & Pes & 155.000 & Pes & 620.000 \\
\hline 8 & Cable & 200 & Meter & 5.000 & Meter & 1.000 .000 \\
\hline 9 & Aluminium rails $2.1 \mathrm{~m}$ & 10 & Pes & 1.500 .000 & Pes & 15.000 .000 \\
\hline 10 & End Clamp & 10 & Pes & 45.000 & Pes & 450.000 \\
\hline 11 & Middle Clamp & 6 & Pes & 45.000 & Pes & 270.000 \\
\hline 12 & The hooks rails & 24 & Pes & 60.000 & Pes & 1.440 .000 \\
\hline 13 & Installation budget & 1 & Pes & 10.000 .000 & Pes & 10.000 .000 \\
\hline 14 & Accu & 24 & Pes & 1.200 .000 & Pes & 28.800 .000 \\
\hline 15 & Battery Charge Regulator & 1 & Pes & 3.500 .000 & Pes & 3.500 .000 \\
\hline 16 & Fluke Amper turn & 1 & Pcs & 3.500 .000 & Pes & 3.500 .000 \\
\hline 17 & Fluke Multimeter & 1 & Pcs & 4.500 .000 & Pes & 4.500 .000 \\
\hline \multirow[t]{2}{*}{18} & Inverter & 1 & Pes & 4.500 .000 & & 4500000 \\
\hline & \multicolumn{5}{|c|}{ TOTAL } & 135.045 .000 \\
\hline
\end{tabular}

Table 4. Price list for Component and Installation of $3000 \mathrm{~W}$ Diesel Generator

\begin{tabular}{|c|c|c|}
\hline No & Remark & Price (Rp) \\
\hline \multirow[t]{4}{*}{1} & Cost of Initial Investment & \\
\hline & Diesel Generator 3000 W & 8.800 .000 \\
\hline & Installation of Diesel Generator & 2.000 .000 \\
\hline & Total & 10.800 .000 \\
\hline \multirow{7}{*}{2} & Operational cost for Energy Output & \\
\hline & on $7.119,325 \mathrm{kWh}$ & \\
\hline & - Fuel Budget & 18.646 .307 \\
\hline & - Oil, Spareparts and Tecnician & 3.729 .261 \\
\hline & (Budget for Services) & \\
\hline & Total & 22.375 .568 \\
\hline & Cost of Year 1 & 33.175 .568 \\
\hline
\end{tabular}

(Spesifik Fuel Oil Comsumption HSD = 0,2331 ltr/kwh [2]

This paper is presented in The $4^{\text {th }}$ International Conference on Maritime Education and Training 
By taking into account the additional expenses cost such as the maintenance and operational cost, namely :

1. The procurement of solar panels for 25 years is :

Maintenance Cost :

$\mathrm{M}=1 \%$ of initial investment (1)

$\mathrm{M}=1 \% \mathrm{x}(\mathrm{IDR}) 135,045,000$

$\mathrm{M}=(\mathrm{IDR}) 13,504,500$

For 25 years $=($ IDR $) 13,504,500 \times 25$ $=($ IDR $) 33,761,250$

Total Investment $=$ Initial Investment Costs + Maintenance Costs $=($ IDR $) 135,045,000+($ IDR $) 33,761,250$ $=($ IDR $) 168,806,250$

2. For the procurement of Diesel Generator set and operational cost for 25 years is

- Purchase of Generator and Installation $=($ IDR $) 10,800,000$

- The operational cost consists of the cost of fuel, oil, spare parts, maintenance is $=($ IDR $) 22,375,568 \times 25=($ IDR $) 559,389,200$

- Total Investment = Initial Investment Costs + Maintenance Costs

$=($ IDR $) 10,800,000+($ IDR $) 559,389,200$ $=($ IDR $) 570,189,200$

\section{The Economic Analysis of Photovoltaic}

The total energy generated per year is $131,232.1 \mathrm{kWh}$, then the revenue generated per year from solar panel is :(IDR)3,380 x 7,119.325 kWh $=\underline{(\text { IDR } 24,063,319}$ per Year

\section{- The Payback Period Method}

The total investment required for the installation of solar panel is (IDR) 168,806,250 then the duration of ROI by using the Payback method can be calculated by using the formula below: [1]

Payback Period $=$ Total Investment $/$ Net Cash Flows

Payback Period $=($ IDR $) 168,806,250 /($ IDR $24,063,319$

Payback Period $=7.02$ Years $=7$ years 7 days

\section{Analysis by Net Present Value (NPV) Method, IRR Method and Profitability Index}

NPV method with the interest rate of $11 \%$ for 25 years, the Solar Panel obtained the value of (IDR)191,247,875,- while the Diesel Genset only obtained the value of (IDR)14,213,808. Similarly to IRR method with the interest rate of $11 \%$ for 25 years, for Solar Panel, the value obtained was $16.11 \%$, which was above the interest rate of $11 \%$ (accepted), while the Diesel Generator set is far below the standard calculation that was \#NUM! (rejected). By the PI method, the use of Solar Panels obtained the value of 1.42 (above 1 = feasible) while the use of Diesel Generators only got 0.43 (below $1=$ not feasible).

\section{Conclusion}

Based on the analysis result on the utilization of the flat surface on TS 02. Sultan Hasanuddin of PIP Makassar by installing the 10 units of solar panel and then by comparing the use of a Diesel Generator with a capacity equal to the output of the Solar This paper is presented in The $4^{\text {th }}$ International Conference on Maritime Education and Training 67 October $8^{\text {th }}$, 2020, Makassar, Indonesia 
Panels then the comparison of the energy costs of Solar Panels and the Diesel Generator, it can be concluded that: for the Solar Panels with the capacity of the output power of 2,331 watts and the max capacity $3000 \mathrm{~W}$ of Diesel Generator with the output power of 2,331 watts then Solar Panels is more profitable than the use of Diesel Genset.

In the future, it is necessary to consider the use of solar panels on the Training Ship 02 Sultan Hasanuddin with a greater power capacity but still in accordance with the surface of the flat areas on the ship receiving the sun lights with regard to the aesthetic factors as well as the safety for the crews.

\section{References}

[1] Afandi, Didin Mukodim, Proceeding PESAT (Psikologi, ekonomi, Sastra, Arsitektur, \&Sipil) Vol .3 Oktober 2009Universitas Gunadarma-Depok 20-21 Oktober 2009 ISSN: 1885-2559, Analisis Studi Kelayakan Investasi Pengembangan Usaha Pt. Aneka Andalan Karya

[2] Badaruddin, Ferdiansyah, Perhitungan Optimasi Bahan Bakar Solar pada Pemakaian Genset, Jurnal Teknologi Mercubuana Jakarta ISSN : 2086-9479, 2015

[3] Dirga Sidauruk, Jurnal 2018, Analisi Kelayakan Investasi Menggunakan Metoda Discounted Cash Flow Tambang Galena PT.Triple Eight Diateh. Teknik Pertambangan Universitas Negeri Padang, 2018

[4] Julay Xty Ludea Yasuha, Analisis Kelayakan Investasi Atas Rencana Penambahan Aktiva Tetap (Studi kasus pada PT Pelabuhan Indonesia III (Persero) Cabang Tanjung Perak Terminal Nilam), Fakultas Ilmu Administrasi Universitas Brawijaya Malang, Jurnal Administrasi Bisnis (JAB)|Vol. 46 No.1 Mei 2017|

[5] Patricia Wruuck, Pricing in retail banking Scope for boosting customer satisfaction \& profitability, Deutsche Bank AG DB Research Frankfurt am Main Germany E-mail: marketing.dbr@db.com Fax: +49 69 910-31877 www.dbresearch.com, 2012

[6] Subandi dan Slamet Hani. 2015. Pembangkit Listrik Energi Matahari Sebagai Penggerak Pompa Air Dengan Menggunakan Solar Cell. Jurnal Teknologi Technoscientia Vol. 7 No. 2, Jurusan Teknik Elektro Institut Sains \& Teknologi AKPRIND Yogyakarta

[7] Suriadi dan Mahdi Syukri, Perencanaan Pembangkit Listrik Tenaga Surya (PLTS) Te(IDR)adu Menggunakan Software PVSYST Pada Komplek Perumahan di Banda Aceh Jurusan Teknik Elektro, Universitas Syiah Kuala Jl. T. Syech Abdurrauf No. 7 Darussalam, Banda Aceh, NAD, Indonesia, Jurnal Rekayasa Elektrika Vol. 9, No. 2, Oktober 2010

[8] Syamsuddin, Lukman. 2011. Manajemen Keuangan Perusahaan. Jakarta: CV Rajawali

[9] Yoga, T. K. 2018. Laporan Tugas Akhir Studi Ekonomi Sistem Penyedia Cadangan Daya Hybrid Bayu-Diesel (Studi Kasus : Di Hotel Queen Of The South Beach Resort) [Skripsi]. Universitas Islam Indonesia, Yogyakarta 